\title{
PENGARUH EKSTRAK DAGING LIDAH BUAYA (Aloe Vera) TERHADAP PENYEMBUHAN ULSERASI MUKOSA MULUT PADA MALE WISTAR RATS
}

\author{
Laila Fitrotuz Zahroh*, Rahmawati Sri Praptiningsih"** Moh. Baehaqi***
}

\begin{tabular}{|c|c|}
\hline & ABSTRACT \\
\hline $\begin{array}{l}\text { Keywords: } \\
\text { ulceration, Aloe vera, } \\
\text { fibroblast }\end{array}$ & $\begin{array}{l}\text { Background: Oral mucosa ulceration which often occurs usually in the } \\
\text { form of white-yellowish spot with concave surface, reddish edge and } \\
\text { pain. Based on previous research, Aloe vera process anti-inflammation } \\
\text { substance that could help quickening ulceration healing process. This }\end{array}$ \\
\hline & $\begin{array}{l}\text { research aims to know the effect of Aloe vera flesh extract on Male } \\
\text { wistar rats oral mucosa ulceration in-vivo. Method: this research was } \\
\text { quasi experimental research with the post-test only control group design } \\
\text { using Male wistar rats as the testing animal. In the research, there were } \\
\text { three treatment groups: The first groups which was given aquadest } \\
\text { treatment, second groups with Aloe vera flesh extract, and third groups } \\
\text { which was given chlorhexidine gluconate } 0,2 \% \text { treatment. The data } \\
\text { collecting was based on histopathology observation concerning the } \\
\text { increase of fibroblast quantity. Result: The research result based on } \\
\text { comparison test among the three groups with One Way Anova showed } \\
\text { that on Day 3th, the average quantity of fibroblast didn't have significant } \\
\text { difference between the treatment group and control group positive that } \\
\text { was p }>0,05 \text {, meanwhile on Day } 7 \text { th every group showed significant } \\
\text { difference p<0,05. Conclusion: It concluded that Aloe vera flesh extract } \\
\text { has influence on the healing of Male wistar rats oral mucosa ulceration } \\
\text { as shown by fibroblast increasing quantity. }\end{array}$ \\
\hline
\end{tabular}

\section{PENDAHULUAN}

Ulserasi merupakan suatu defek dalam epitelium berupa lesi dangkal berbatas tegas yang disertai dengan menghilangnya lapisan epidermis di atasnya ${ }^{1}$. Ulserasi mukosa mulut dapat disebabkan oleh beberapa faktor diantaranya trauma, stomatitis aptosa rekuren, penyakitpenyakit mukokutaneus, infeksi bakteri, infeksi virus dan jamur2. Jumlah kejadian ulserasi mukosa mulut dialami sekitar $20 \%$ dari jumlah populasi yang ada, terutama banyak terjadi pada orang tua dan remaja ${ }^{3}$.

Pengobatan ulserasi mukosa mulut dapat menggunakan obat kumur yang mengandung antibakteri ${ }^{4}$. Obat kumur yang sering digunakan untuk mengobati ulserasi mukosa mulut adalah klorheksidin4. Klorheksidin merupakan obat kumur yang berasal dari derivat disquanid dan umumnya digunakan dalam bentuk glukonat. Klorheksidin mempunyai efek antibakteri dengan spektrum luas, efektif terhadap bakteri gram positif, gram negatif, sel ragi dan jamur. Klorheksidin juga efektif dalam menurunkan radang mukosa mulut dan akumulasi plak ${ }^{4}$.

Pengobatan alternatif untuk menyembuhkan ulserasi mukosa mulut dapat menggunakan tanaman obat, salah satunya adalah lidah buaya (Aloe vera $)^{5}$. Berdasarkan penelusuran berbagai literatur, lidah buaya terbukti mampu menjadi tanaman obat yang berkhasiat sebagai obat anti inflamasi, anti jamur, anti bakteri dan regenerasi sel $^{6}$. Kandungan gizi yang terdapat dalam daging lidah buaya mengandung berbagai karbohidrat polimer, terutama glukomanosa atau asam peptik, dan berbagai macam komponen

${ }^{*}$ Program Pendidikan Dokter Gigi UNISSULA, ${ }^{* *}$ FKG Universitas Islam Sultan Agung, ${ }^{* * *}$ DKK Kabupaten Demak

Korespondesi: Laila Fitrotuz Zahroh (lailafitrotuz@gmail.com) 
organik dan anorganik. Pemberian ekstrak lidah buaya dilaporkan mampu mengurangi pembentukan prostaglandin dari asam arakidonat, dangan cara mengahambat enzim siklooksigenase, sehingga mempunyai sifat anti inflamasi dan analgesik, untuk itu lidah buaya dapat digunakan sebagai obat luka .

Penelitian ini bertujuan untuk mengetahui pengaruh pemberian ekstrak daging lidah buaya (Aloe vera) 100\% terhadap proses penyembuhan ulserasi mukosa mulut Male wistar rats. Proses penyembuhan ulserasi mukosa mulut Male wistar rats dilihat berdasarkan peningkatan jumlah fibroblas setelah diberi perlakuan dengan pemberian akuades sebagai kontrol negatif, pemberian ekstrak daging lidah buaya (Aloe vera) dan pemberian obat kumur klorheksidin glukonat $0,2 \%$ sebagai kontrol positif.

\section{METODE PENELITIAN}

Penelitian ini merupakan penelitian eksperimental semu dengan rancangan the post test-only control group design. Dalam penelitian ini menggunakan sampel Male wistar rats sebanyak 24 ekor dengan umur 4 bulan dan berat badan antara 200-250 gram.

Alat dan bahan yang digunakan dalam penelitian ini antara lain adalah satu set alat bedah minor, satu set alat untuk pembuatan preparat dengan pewarnaan hematoksilin eosin, blander dan micro brush. Bahan penelitiannya adalah ekstrak daging lidah buaya (Aloe vera) $100 \%$, obat kumur klorheksidin glukonat $0,2 \%$, larutan akuades, alkohol $70 \%$, $80 \%, 90 \%, 96 \%$, Hidrogen peroksida $\left(\mathrm{H}_{2} \mathrm{O}_{2}\right) 30 \%$ dan etanol $96 \%$.

Hewan coba dibagi secara acak menjadi 3 kelompok yang masing-masing berjumlah 4 ekor. Setiap hewan coba diberi perlukaan dengan pemberian hidrogen peroksida $\left(\mathrm{H}_{2} \mathrm{O}_{2}\right) \quad 30 \%$ pada bagian mukosa labial di bawah frenulum insisivus sentral rahang bawah. Kelompok 1 sebagai kelompok kontrol negatif diberikan akuades, kelompok 2 diberi ekstrak daging lidah buaya dan kelompok 3 sebagai kelompok kontrol positif diberi obat kumur klorheksidin glukonat $0,2 \%$.

Perlakuan diberikan setiap hari selama 7 hari. Pada hari ke tiga sebanyak 4 ekor hewan coba dari masing-masing kelompok dimatikan. Hewan coba yang telah dimatikan kemudian dibiopsi dan dibuat preparat histologi. Sisa hewan coba dimatikan pada hari ke 7 kemudian dilakukan biopsi dan dibuat preparat histologi dengan pewarnaan hematoksilin eosin. Preparat histologi diamati dengan menggunkan mikroskop cahaya dengan pembesaran 400x dan 100x. Pengamatan histopatologi dilihat dari peningkatan jumlah fibroblas pada setiap kelompok perlakuan.

\section{HASIL PENELITIAN}

Pada penelitian ini didapatkan data peningkatan jumlah fibroblas yang diamati secara histopatologi pada yang menunjukkan peningkatanjumlah fibroblas pada semua kelompok perlakuan. Pada hari ke 3 peningkatan jumlah fibroblas tidak begitu banyak dibandingkan pada hari ke 7. Untuk mengetahui kebermaknaan jumlah fibroblas antar kelompok maka dilakukan uji parametrik Anova, yang sebelumnya dilakukan uji normalitas dan homogenitas. Berdasarkan uji normalitas dan homogenitas didapatkan $p>0,05$ yang berarti data terdistribusi normal dan homogen sehingga uji parametrik Anova dapat dilakukan. Hasil uji Anova didapatkan $p<0,05$ yang berarti data signifikan dan dapat dilakukan uji selanjutnya yaitu uji post hoc.

Dari hasil uji Post Hoc diketahui bahwa nilai $p$ antara kelompok perlakuan dengan kontrol positif pada hari ke 3 menunjukkan hasil $p>0,05$ yaitu 0,100 itu berarti tidak ada perbedaan yang bermakna antara kelompok perlakuan dengan kontrol positif yang berarti ekstrak daging lidah buaya dengan obat kumur klorheksidin glukonat $0,2 \%$ memiliki kemampuan yang sama dalam peningkatan jumlah fibroblas. Nilai p pada hari ke 7 antara kelompok satu 
dengan yang lainnya adalah 0,000 dan 0,032 itu berarti nilai $p<0,05$ sehingga terdapat perbedaan yang bermakna antara kelompok satu dengan yang lain.

\section{DISKUSI}

Proses penyembuhan luka merupakan proses yang sangat penting untuk mendapatkan kembali kontinuitas jaringan tubuh. Proses ini merupakan proses kompleks yang terdiri dari beberapa fase, yaitu: inflamasi, proliferasi dan maturasi ${ }^{8}$. Dalam mempercepat proses penyembuhan luka dapat diberikan obat alternatif dari herbal ${ }^{5}$.

Pemberian ekstrak daging lidah buaya pada penelitian ini memang berpengaruh terhadap kenaikan jumlah fibroblas pada hari ke 3 dan ke 7 . Pada hari ke 3 peningkatan jumlah fibroblas tidak terlalu banyak dibandingkan dengan jumlah fibroblas pada hari ke 7. Peningkatan jumlah fibroblas dimulai pada hari ke 3 dan mencapai puncaknya pada hari ke 7 , sehingga jumlah fibroblas pada hari ke 3 tidak terlalu banyak dibandingkan dengan hari ke $7^{9}$. Peningkatan jumlah fibroblas ini dipengaruhi oleh accemanan dan saponin yang terkandung dalam ekstrak daging lidah buaya yang mempunyai sifat antibakteri dan imunomodulator dapat menstimulasi makrofag, limfosit, interleukin, sitokin dan TNF yang dapat mempengaruhi kepadatan jumlah fibroblas ${ }^{10}$.

Hasil uji statistik pada penelitian ini menunjukkan bahwa terdapat perbedaan yang tidak bermakna pada kelompok kontrol positif dan kelompok perlakuan dengan ekstrak daging lidah buaya pada hari ke 3. Kelompok kontrol positif yang diberi perlakuan dengan pemberian obat kumur klorheksidin glukonat 0,2 \% dapat berperan dalam peningkatan jumlah fibroblas karena efek antibakteri yang dimilikinya. Efek antibakteri ini mampu mengurangi kontaminasi bakteri dalam mulut yang dapat mengganggu proses penyembuhan ulserasi ${ }^{11}$. Kelompok perlakuan dengan lidah buaya juga memperlihatkan jumlah fibroblas yang meningkat karena efek antiinflamasi dan antibakteri yang dimilikinya, sehingga mampu mempercepat proses penyembuhan ulserasi mukosa mulut Male wistar rats ${ }^{12}$. Berdasarkan kemampuan obat kumur klorheksidin glukonat 0,2 $\%$ dan ekstrak daging lidah buaya sebagai antibakteri sehingga keduanya mempunyai pengaruh yang sama dalam penyembuhan ulserasi mukosa mulut male wistar rats.

Hasil uji statistik pada hari ke 7 didapatkan hasil $p<0,05$ yang berarti antara kelompok perlakuan dengan ekstrak daging lidah buaya dan kelompok kontrol positif terdapat beda yang bermakna. Pada hasil penelitian jumlah fibroblas pada kelompok kontrol positif lebih banyak dibandingkan dengan kelompok perlakuan dengan ekstrak daging lidah buaya, hal ini dikarenakan oleh kemampuan obat kumur klorheksidin glukonat $0,2 \%$ sebagai antibakteri berspektrum luas yang efektif terhadap bakteri gram positif dan gram negatif. Obat kumur klorheksidin glukonat $0,2 \%$ sebagai antibakteri yang berspektrum luas dapat bersifat bakteriostatik atau bakterisid. Berdasarkan kemampuan tersebut obat kumur klorheksidin glukonat $0,2 \%$ dapat membunuh bakteri lebih banyak disekitar daerah ulserasi sehingga penyembuhan luka lebih cepat dengan jumlah fibroblas yang banyak ${ }^{13}$.

Hasil penelitian menunjukkan jumlah fibroblas pada kelompok perlakuan ekstrak daging lidah buaya tidak begitu banyak, kerena kemampuan anti bakteri pada lidah buaya hanya efektif pada bakteri gram positif6. Kemampuan ini menyebabkan tidak semua bakteri yang ada disekitar ulserasi mati, sehingga kontaminasi bakteri dapat terjadi pada daerah ini dan menyebabkan jumlah fibroblas yang terbentuk tidak banyak dibandingkan pada kelompok kontrol positif. 


\section{KESIMPULAN}

Berdasarkan hasil penilitian terdapat perbedaan yang signifikan antara perlakuan dengan ekstra daging lidah buaya dengan obat kumur klorheksidin glukonat $0,2 \%$. Ekstrak daging lidah buaya (Aloe vera) dapat membantu proses penyembuhan ulerasi mukosa mulut Male wistar rats dan dapat meningkatkan jumlah fibroblas yang dapat membantu mempercepat proses penyembuhan ulserasi mukosa mulut sehingga ekstrak daging lidah buaya dapat digunakan sebagai obat alternatif ulserasi mukosa mulut Male wistar rats.

\section{DAFTAR PUSTAKA}

1. Greenberg, M S. Glick, M, Ship, J A.. Burket's Oral Medicine. BC Decker Inc: Hamilton, Ontario, 2008, pg 41

2. Lewis, M A, Lamey, P J (ed). Tinjauan Klinis Penyakit Mulut. Penerbit Widya Medika: Jakarta, 2012, pg 47-50

3. Bertini, dkk. Ulceration of the oral mucosa induced by antidepressant medication: a case report. Brazil: Jurnal of Medical Case Report Biomed Central, 2009, pg 1-2

4. Eley, B M dan Manson, J D.. Periodontics. (5thed). Wright: London, United Kingdom, 2004, pg 209-210

5. Kalangi, S J R. Khasiat Aloe Vera pada Penyembuhan Luka. Bagian AnatomiHistologi Fakultas Kedokteran Universitas Sam Ratulangi Manado: BIK Biomed, 2007, Vol.3, No.3, pg 108-109

6. Joshep, B, Raj, S J. Pharmacognostic And Phytochemical Properties OfAloe Vera Linn -An Overview. Interdisciplinary Research
Unit, Departmentof Biotechnology, Malankara Catholic College, Mariagiri, K.K District: International Journal of Pharmaceutical Sciences Review and Research, 2010, Vol. 4, No. 2, pg 107

7. Ghosh, A K dkk., A Study On Analgesic Efficacy And Adverse Effects Of Aloe Vera In Wistar Rats. Department of Pharma cology, Medical College and Hospita Kolkata, India: Pharmacologyonline I, 2011, No. 1, pg 1099

8. Robbins, S L, Kumar, V, Cotran, R S (ed). Buku Ajar Patologi I. EGC: Jakarta, 2007, pg 52-78

9. Prabakti, Y. Perbedaan Jumlah Fibroblas Di Sekitar Luka Insisi Pada Tikus yang diberi Infiltrasi Penghilang Nyeri Levobupivakain Dan Yang Tidak Diberi Levobupivakain.Semarang: Univesitas Diponegoro Semarang, 2005

10. Agarwal, S, Sharma, T R. Multiple Activities of Aloe Barbadensis (Aloe Vera): An Overview. India: Asian Journal of Pharmacy \& Life Science 2011, Vol.1, No. 2, pg 196-197

11. Gupta, R, Candhavarkar,V, Galgali, S.R, Mishra, M. Chlorhexidine, A Medicine for all the Oral Diseases. New Delhi: Global Journal of Medicine and Public Health, 2012, pg 44-45

12. Tjahajani, A, Widurini. Aloe vera Leaf Anti Inflamation's Activity Speeds Up the Healing Proccess of Oral Mucosa Ulceration. Jakarta: Journal of Dentistry Indonesia 2011, Vol. 18, No. 1, pg 17-20

13. Cappelli, D P, Mobley, C C. Prevention in Clinical Oral Health Care Mosby Elseiver: The University of Michigan, 2008, pg 220221 